\title{
Are Rural Stakeholder Needs Compliant with the Targets of the Europe 2020 Strategy? Text Mining Analysis of Local Action Group Strategies from Two Polish Regions
}

\author{
Marek FURMANKIEWICZ ${ }^{1 *}$, Krzysztof JANC ${ }^{2}$, Iwona KACZMAREK ${ }^{1}$, and \\ Iga SOLECKA ${ }^{1}$ \\ 1 Wrocław University of Environmental and Life Sciences, Wrocław, Poland; marfurm@interia.pl \\ 2 University of Wrocław, Wrocław, Poland \\ * Correspondence: marek.furmankiewicz@upwr.edu.pl; marfurm@interia.pl
}

\begin{abstract}
The 1990s saw a considerable facilitation of the concept of area-based cooperation between stakeholders from the public, economic and social sectors in the European Union (EU) with regard to local resource management. EU support programmes have given rise to community-based partnerships referred to as Local Action Groups (LAGs), in which the stakeholders involved formulate local development strategies, the implementation of which is subsequently made possible through the external financial support of EU funds. This paper illustrates an attempt to assess the extent to which local strategies are consistent with the EU's Europe 2020 strategy, using the example of 27 LAGs from two Polish provinces. Text mining and content analysis are two methods employed herein. The analysis served to establish that the dominant issues for rural areas, that are correspondent to the Europe 2020 strategy, revolve around increasing employment, educating local communities and combating poverty through the use of social inclusion methods, with much less attention dedicated to the issues of greenhouse gas emission reduction and renewable energy development. The strategies in question emphasise innovation with regard to planned activities, insofar as it is perceived at the local level, which usually bears no relation to methodical research and development (R\&D) work.
\end{abstract}

Keywords: Europe 2020 strategy; Europeanisation processes; area-based partnerships; Local Action Groups; Local Development Strategies; content analysis; text mining

JEL Classification: O21; D71; L31

\section{Introduction}

Initially prevalent within the liberal democracies of Anglo-Saxon countries and later propagated throughout the European Union (EU), the idea of local, area-based, cross-sectoral partnerships towards local development boasts a tradition of over 30 years (Esparcia \& Abbasi, 2020; Hutchinson, 1994; Moseley, 2003; Rounds, 1993). The support for the development of partnerships in rural areas stemmed from the conviction that previous methods of top-down, exogenous development, focusing on the maximisation of agricultural production, were marred by a poor level of adaptation to local needs and 
introduced many negative social and environmental effects (Boukalova et al., 2016; Furmankiewicz \& Janc, 2012). Methods of managing local resources based on the idea of territorial governance have thus began to be supported on a larger scale (Moseley, 2003; Thuesen \& Nielsen, 2014). At their core, they are associated with the concept of neo-endogenous development in an attempt to combine local and extra-local (national, pan-European) needs and aims (Ray, 2006), through local activities partially steered by subsidies from external support programmes (Böcher, 2008; Bosworth et al., 2020; Furmankiewicz \& Campbell, 2019). The development of this approach in the EU began in 1991 with the creation of area-based partnerships referred to as Local Action Groups (LAGs), which itself was part of the implementation process for three LEADER Community Initiatives (1991-2006) and the national programmes which strived to imitate them (Furmankiewicz et al., 2015; Navarro, Cejudo, et al., 2016). This was followed by the establishing of the LEADER Axis found in national Rural Development Programmes (2007-2013) and the Community Led-Local Development (CLLD) approach (2014-2020) (Apostolopoulos et al., 2020; Konečný, 2019).

A rich body of literature is available on issues related to the cooperation of various stakeholders within LAGs and the local strategies which they implement (Cejudo \& Navarro, 2020; Rodriguez et al., 2019; Moseley, 2003), yet the question of the compliance of local strategies formulated by local stakeholders (with NGO participation) with the pan-European goals expressed in the Europe 2020 strategy - which is also related to the concept of Europeanisation (Dąbrowski, 2012; Székely, 2017) - is dedicated much less academic attention. Numerous studies indicate that EU funds are not always utilised in accordance with the strategies and rules defined by their policymakers (European Court of Auditors, 2010), and are not invariably conducive to levelling unequal development (Canete et al., 2018; Chruscinski et al., 2019). It also remains to be settled whether CLLD should be based entirely on local needs or perhaps take into account extra-local (national, pan-European) regulations and recommendations; this, in turn, leads to the problem of balancing these two dimensions of needs (Furmankiewicz, Królikowska et al., 2020; Navarro, Woods et al., 2016).

With the above-mentioned concerns in mind, the aim of this paper is to attempt at assessing whether the goals and tasks set out in Local Development Strategies for LEADER type partnerships (and based on the needs of local stakeholders) take into account the implementation of pan-European goals specified in "Europe 2020. A strategy for smart, sustainable and inclusive growth", announced in 2010, and designed for the years 2010-2020 (European Commission, 2010). Towards this end, the authors use the example of LAG strategies from two Polish voivodeships (self-governing provinces): województwo dolnoślaskie (Lower Silesia Province) and województwo opolskie (Opole Province). One additional aim of this preliminary research is to develop and discuss the use of text mining computer methods in analysing LAG strategy content. 


\section{The Europe 2020 Strategy and Community-Led Local Development}

EU budgets are organised in seven-year cycles referred to as programming periods. The Programming Period 2014-2020 saw the application of the Europe 2020 strategy announced in 2010 (European Commission, 2010). The strategy defines the three main priorities of growth as "smart", "sustainable" and "inclusive" (Bartniczak, 2012). Smart growth involves economical development based on knowledge and innovation; sustainable growth entails the promotion of a greener, more resource-efficient and competitive economy; inclusive growth is focused around supporting a high-employment economy in order to deliver social and territorial cohesion. These three priorities were elaborated in five quantifiable targets (European Commission, 2010):

Target 1: The employment rate for population aged 20-64 was to be increased to a minimum of $75 \%$.

Target 2: 3\% of EU GDP was to be invested in Research and Development.

Target 3: Greenhouse gas emissions were to be reduced to at least $20 \%$ compared to levels from 1990, the share of renewable energy in final energy consumption was to reach a minimum of $20 \%$ with energy efficiency increasing to a minimum of $20 \%$.

Target 4: The share of early school leavers was to remain under $10 \%$ with at least $40 \%$ of the population aged 30-34 having a tertiary degree.

Target 5: The number of people at risk of poverty was to be decreased by about 20 million persons.

As a rule, the targets were formulated for the whole of EU (i.e. the indicators they outline would not have to be achieved individually by all member states), though each and every member state was obliged to include them in all programmes financed through the use of EU funds. Most LAGs in Poland were financed from the Polish Rural Development Programme for 2014-2020 (in turn financed from both EU and national funds), which partially acknowledged the above-mentioned objectives, in spite of them being less clearly specified than in their original European documents (Furmankiewicz, Królikowska et al., 2020). The LAGs themselves developed their strategies (Local Development Strategies LDS) from the bottom up, based on the needs of local communities, but they had to comply with the national Act of 20/02/2015 on local development with the participation of the local community (Journal of Laws, item 378, Warsaw, Poland). The need to follow the guidelines of national documents imposed the following rules upon LAG strategies for rural areas (Ministerstwo Infrastruktury i Rozwoju, 2014): the principal area for LDS implementation had to consist of at least 2 communes (rural, urban-rural or small urban municipalities); LDS boundaries could not run through the internal areas of communes, but were not required to coincide with the boundaries of poviats (counties) and voivodeships (provinces); LDS were to be implemented in areas with populations ranging between 30,000 and 150,000 inhabitants.

The development of LAGs in Europe is related to the popularity of the concept of neo-endogenous development (Ray, 2006), which some authors consider to be a "successful combination" of the extreme models of exogenous (top-down) and endogenous (grass-roots - 
completely bottom-up and based on local resources) development planning (Böcher, 2008). The concept involves supra-local institutions (state authorities or interstate organisations such as the EU) endorsing those bottom-up initiatives by local inhabitants which remain consistent with the goals set out in central strategies but refraining from imposing any specific actions on them. Since their activity is meant to be supported through funds from the EU, LAGs needed to be contractually obligated to ensure that their local strategies-established in the process of voluntary, bottom-up cooperation of local stakeholders-remain consistent with the objectives of national support programmes, which, in turn, have to be compatible with pan-European EU strategies and recommendations. LDS were additionally required to demonstrate the compliance of local activities with the objectives of the Polish Rural Development Programme (Ministerstwo Rolnictwa i Rozwoju Wsi, 2019), which itself had to be consistent with the objectives of the Europe 2020 strategy.

Assessing local strategies and evaluating their implementation is important both in its theoretical and practical aspects with regard to public policy and the disbursement of public funds (Kis et al., 2012). Literature on the subject abounds in technical and economic evaluations of LAG organisational features and their activities (Vrabková \& Šaradín, 2017; Biczkowski, 2020), yet it is much more demanding to analyse the compatibility of local goals with those set out in superordinate strategies and documents, as it often requires the use of a qualitative analysis - not all activities can be easily quantified with performance indicators. Currently available research makes use of the distinction between endogenous, exogenous and hybrid evaluations, the latter combining both local and supra-local (national, EU) goals (High \& Nemes, 2007). The approach adopted in this paper serves to assess the extent to which the extra-local goals expressed in the Europe 2020 strategy have been reflected in the strategies of local rural communities, by means of a top-down, endogenous evaluation.

\section{Methodology}

The analysis involves LAG strategy documents in Polish, established for the 2014-2020 European Programming Period. The Europe 2020 strategy has already been published at the time when local communities began working on their strategies - in 2015 - which allowed them to acknowledge the pan-European aims it had introduced.

The authors have chosen to use the text analytics method, also referred to as 'text mining', which is defined as a process aimed at obtaining useful, high-quality information from text data (Gaikwad et al., 2014). Text mining methods include: keyword search, machine learning, and linguistic and statistical techniques (Hotho et al., 2005). As a means of content analysis, it is used to search for keywords and key phrases in many scientific disciplines (Krajewski \& Solecka, 2019; Szewrański \& Kazak, 2020).

Analysis of any text material, due to the unstructured nature of the medium involved, is much more complex than analyses of numerical data. The complexity of the Polish language (which involves e.g. inflection of nouns by 7 grammatical cases and 3 genders, as well as adjectives by cases, numbers and genders, or verbs by persons and numbers) makes it much more difficult to successfully utilise machine processing when compared to e.g. English. 
This makes it problematic to use ready-made text mining software designed with the latter in mind. For this reason, this study herein makes use of a two-step analysis of LAG strategy content: an initial computer search based on keywords which is followed by manual content analysis during which the automatically retrieved results are verified by authors.

In the first phase, the authors individually prepared a list of words that may appear in local strategies as part of expressions describing activity related to the implementation of a given target from the Europe 2020 strategy (the heuristic method). Next, through the process of discussion, they made use of the expert method, selecting from 2 to 5 words or word roots, which, in their opinion, were best suited as search keywords for the analysis.

The second phase of the analysis involved an automated search for the previously selected words and word roots within complete sentences from the text of a given LAG strategy (Table 1). The search was performed using a script prepared in the Python programming language, and aimed at identifying full sentences containing the keywords. The result of this computer-based text mining process was a list of expressions $(6,291$ records), with accompanying quantitative data on the number of keywords found in individual documents.

Table 1. The keywords used in text mining procedures. Original elaboration by the authors and Europe 2020 strategy (European Commission, 2010).

\begin{tabular}{|c|c|c|}
\hline Short name & $\begin{array}{c}\text { Europe } 2020 \text { aim } \\
\text { (European Commission, 2010) }\end{array}$ & $\begin{array}{l}\text { Search word roots or words (in Polish) and } \\
\text { related collocations (translated in English) }\end{array}$ \\
\hline 1.Employment & $\begin{array}{l}\text { The employment rate of the population } \\
\text { aged } 20-64 \text { should increase to } \min .75 \%\end{array}$ & $\begin{array}{c}\text { "zatrudn" (increasing employment); "pracy" } \\
\text { (jobs, labour market); "zawodow" } \\
\text { (professional activation); "bezroboc" } \\
\text { (counteracting unemployment) }\end{array}$ \\
\hline 2. R\&D & $\begin{array}{c}3 \% \text { of the EU's GDP should be invested in } \\
\text { the Research and Development }\end{array}$ & $\begin{array}{c}\text { "naukow" (research); "innowac"(searching for } \\
\text { innovative solutions) }\end{array}$ \\
\hline $\begin{array}{l}\text { 3. Greenhouse } \\
\text { gas }\end{array}$ & $\begin{array}{l}\text { Greenhouse gas emissions should be } \\
\text { reduced to at least } 20 \% \text { (...), renewable } \\
\text { energy should achieve a min. } 20 \% \text { share in } \\
\text { final energy consumption, while energy } \\
\text { efficiency should increase to a min. of } 20 \%\end{array}$ & $\begin{array}{l}\text { “energ” (renewable energy, energy saving, } \\
\text { energy efficiency); “cieplarn” (greenhouse } \\
\text { gases); “ciepła” (heat pump); } \\
\text { “termomodernizac" (thermo-modernisation); } \\
\text { "solar" (solar installations) }\end{array}$ \\
\hline 4. Education & $\begin{array}{l}\text { The share of early school leavers should be } \\
\text { maintained under } 10 \% \text { and at least } 40 \% \text { of } \\
\text { the population aged } 30-34 \text { should have a } \\
\text { tertiary degree }\end{array}$ & $\begin{array}{c}\text { "kształc" (education, increasing the quality of } \\
\text { education); "edukac" (educational activities, } \\
\text { youth education) }\end{array}$ \\
\hline 5. Poverty & $\begin{array}{c}\text { The number of people being at risk of } \\
\text { poverty should decrease by about } 20 \\
\text { million persons }\end{array}$ & $\begin{array}{l}\text { "ubóstw" (combating poverty, preventing } \\
\text { poverty); “wyklucz" (counteracting social } \\
\text { exclusion); “włączeni” (actions towards social } \\
\text { inclusion). }\end{array}$ \\
\hline
\end{tabular}

Note: Examples of words excluded during pre-qualification: entrepreneurship, renewable, university, training, didactic, homelessness.

In the third phase of the analysis, the context of the words and phrases used in the text was manually verified with regard to whether a given fragment was actually related to the targets outlined in the Europe 2020 strategy. Sentences not meaningfully related to their targets were promptly removed from the list, with those related to goals, needs and action plans being retained (content interpretation). Material related to the assessment of the 
existing state of socio-economic development has been purposefully omitted, reducing the number of records to 2,895. The last phase revolved around a statistical analysis of records qualified for analysis, in an attempt to assess the level of importance of a given topic, as ascribed by the creators of the strategy.

The analysis involved LAGs from two provinces: Lower Silesia (with the capital in Wrocław) and Opole (with the capital in Opole) (Figure 1)-which constitute a single EU NUTS-1 statistical region - with the intentional omission of LAGs with headquarters located outside of this area, as well as one specialist Fisheries LAG from the Opole Province. In total, the analysis covered 27 LAGs (17 from Lower Silesia, 10 from the Opole Province). The area in question is characterised by a diversified economical structure, with industry and tourism playing a significant role and agriculture remaining complementary (Stacherzak \& Hełdak, 2019; Struś et al., 2020).

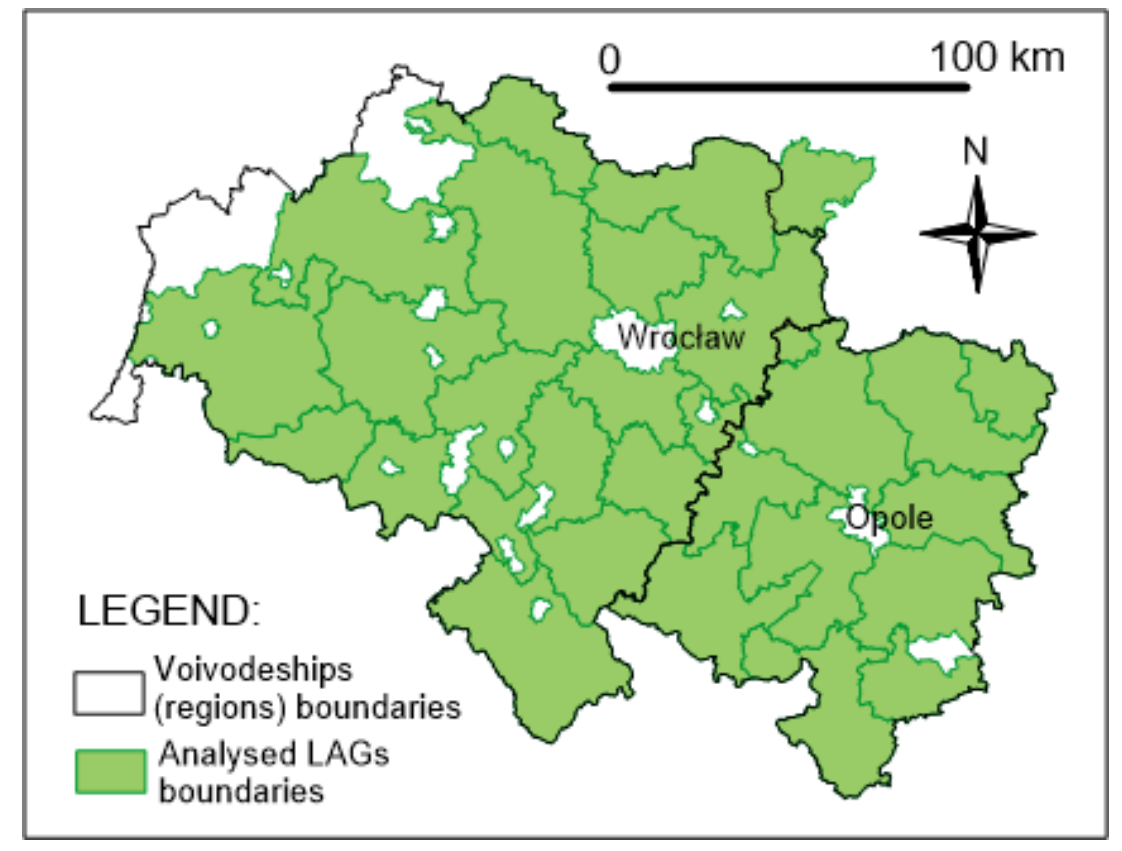

Figure 1. The areas of analysed LAGs with headquarters in the Lower Silesia and Opole provinces.

Source: Authors' elaboration.

Taking into account the small number of available methods aimed at assessing the compliance of local development strategies with superordinate strategies (Vrabková \& Šaradín, 2017), this paper should be considered a preliminary study, serving to discuss and validate the usefulness of the methods adopted in the research it serves to illustrate.

\section{Results}

Among the 27 LAGs surveyed, only 14 (52\%) included any reference to the Europe 2020 strategy in their own strategies (Figure 2), with more results available in LAGs from the Lower Silesia (65\%) when compared to those operating in Opole Province (30\%).

Target 1 of the Europe 2020 strategy (increasing employment) proved to be the most highly referenced in the analysed documents - this usually involved records indicating the need to create new jobs (Figure 3). 


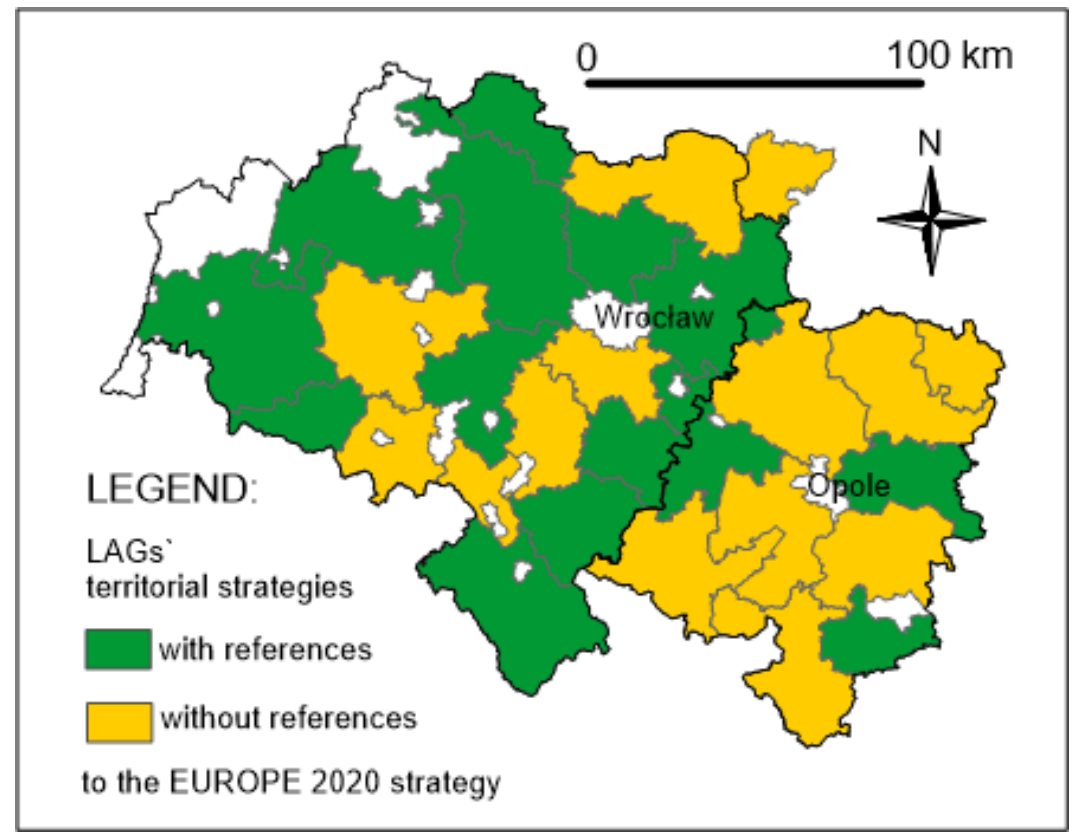

Figure 2. LAG territorial strategies with and without references to the Europe 2020 strategy. Source: Authors' elaboration.

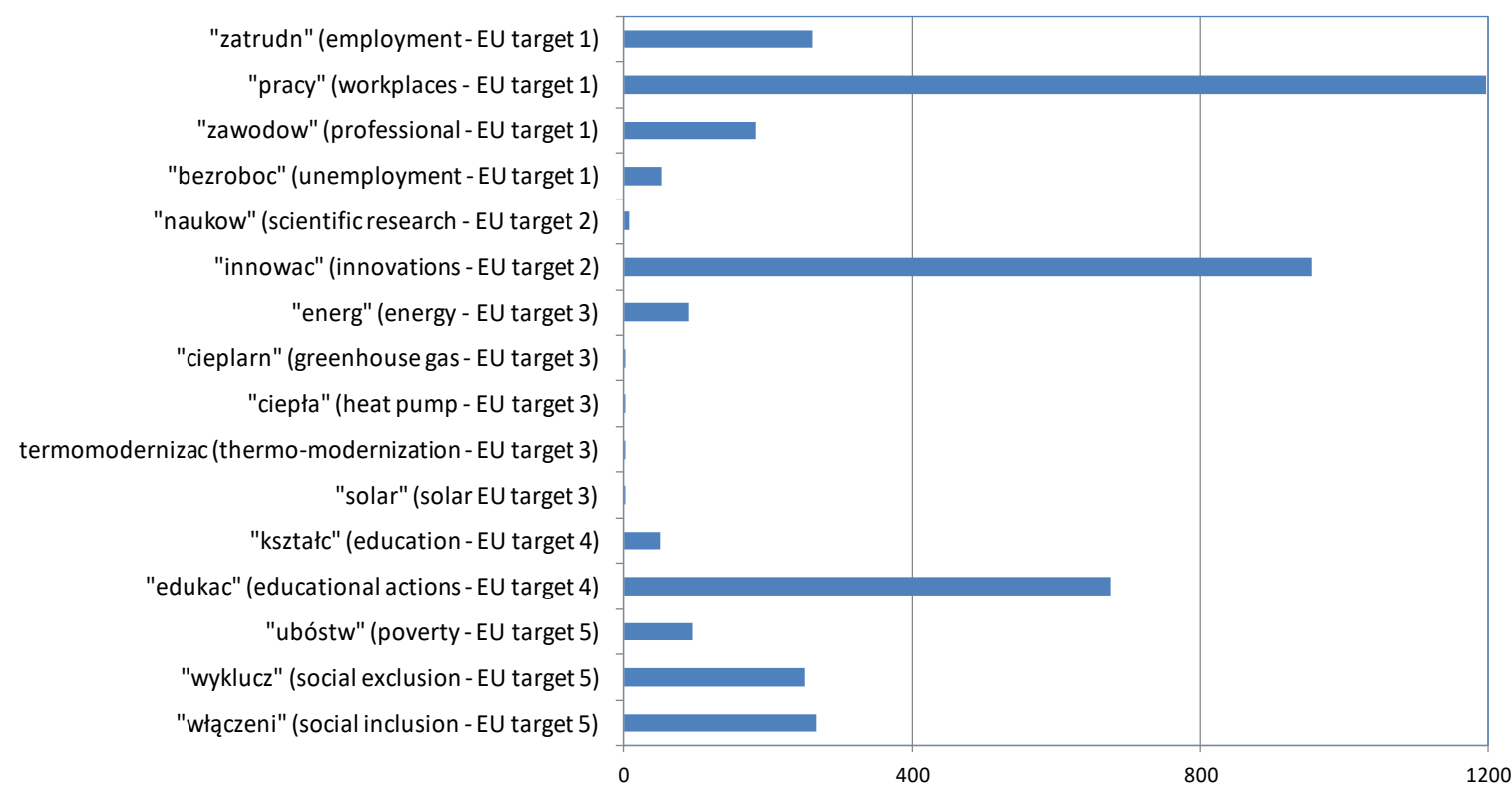

Figure 3. The number of analysed keywords found by means of text mining after being verified as partially or fully related to EU Europe 2020 targets. Source: Authors' elaboration.

Innovation was the second target most likely to be found in the studied documents this was usually related to specific activities planned by the LAGs. However, further content analysis shows that the innovation in question was limited to a local scale, which meant that the use of recognised and familiar technologies and methods was also considered innovative, as long as they have not yet been used locally. Practically no information was available regarding the willingness to support research and development projects (there were no collocations of the "research" type). Only two LAGs have made explicit references to such endeavours, as their strategies mentioned the need for "a policy to support cooperation 
between science and business (and thus support the development of innovation)" (LAG Kłodzka Wstęga Sudetów) or the need to support "research and development activities" (LAG Kraina św. Anny).

The third most frequently planned type of activity involved education, which corresponds with objective 4 of the Europe 2020 strategy. The education in question was, however, most often addressed to the general population and thus contained postulates of lifelong learning, intended for people of working and retirement age. While a significant portion of planned activity was also aimed at educating the youth, none of it was directly related to the goal of supporting them in obtaining higher education and afterwards returning to the area served by the LAG (e.g. scholarships, stipends, tutoring and other similar means of assistance). It is effectively only in large cities that young people are offered the possibility of obtaining higher education within the areas under analysis, which often entails the need for the rural youth to move into those urban centres. It is worth noting that the education-related activity outlined in LAG strategies centred around a variety of aspects of development, including the historical and cultural heritage of the region, ecological issues, as well as the fundamentals of entrepreneurship.

The authors of the strategies have dedicated significant attention to issues of social inclusion. This was most commonly addressed through activity aimed at social and economic activation (mobilisation) of the population, and was commonly accompanied by matters of combating poverty (Europe 2020 target 5), with focus on disadvantaged groups, whose deficiency was often linked to a lack of economic or professional activity.

Environmental issues have been given the least attention in the LAG strategies analysed in this study, with rare references to the implementation of measures aimed at counteracting climate change, including the reduction of greenhouse gas emissions. This holds true with regard to the relatively low amount of activity and projects designed to support the development and distribution of renewable energy to individual households and public facilities (both in terms of heating and electricity). This subject was clearly held in less regard by the local communities than the previously mentioned social and economic issues.

\section{Discussion and Conclusions}

The outcomes of the analysis serve to demonstrate that the most common issue addressed within the investigated partnerships and found to be compatible with the Europe 2020 strategy was the creation of workplaces, often associated with support for entrepreneurship. Other published research results show that such goals are indeed considered high priority by LAGs both in Poland (Furmankiewicz \& Campbell, 2019; Hoffmann \& Hoffmann, 2018) and in other countries (Camacho et al., 2020).

Both in our analyses and in available literature on the subject, the issues of social inclusion and activation of local communities emerges as one of the most important goals of the LAGs and public sector (Furmankiewicz et al., 2016; Hełdak et al., 2018; Kola-Bezka, 2020). Much attention is paid to matters of social inclusion of disadvantaged groups (Navarro, Cejudo et al., 2016) and to the socio-cultural intangible values of partnership co-operation (Castellano-Álvarez et al., 2020). Educational activities are perceived as an 
essential element required to increase human capital, which is in turn viewed as crucial with regard to the functioning of citizens on the labour market, i.e. finding a job or starting a business (Camacho et al., 2020). All this points to the solving of social issues as being among the most important goals pursued through LAG activity (Zajda, 2014). LAG strategies frequently include provisions supporting the education of young people in the areas they operate in, though there was no clear indication of the goal of increasing the number of people who would receive higher education and return to their place of residence.

Innovation is another aspect with a significant presence within the documents examined in this study, though it rarely referred to systematic research activities aimed at improving the quality of a service or product, as it is usually defined in R\&D definitions (Witherick et al., 2001), but rather involved vague notions of "new ideas" and "innovative projects". The strategies prioritised the undertaking of innovative activities by local entrepreneurs and farmers, and made frequent use of the idea of supporting social innovation, with some authors choosing to stress the significant role played by LAGs in this regard (Novikova et al., 2020). The expressed need to introduce new solutions serves to prove that there is a general awareness of the fact that when compared to urban areas and industrial districts, rural areas are characterised by a low level of actions aimed at innovation (Janc et al., 2020), and a poor degree of implementing information technologies (Galindo-Pérez-de-Azpillaga \& Foronda-Robles, 2018) - a clear indication that they require additional support for this type of initiatives.

The subject of renewable energy sources was barely present in the studied material. The relatively low interest in matters related to climate change and the development of renewable energy sources had already been observed for rural LAGs in Poland (Furmankiewicz, Hewitt et al., 2020) and in other countries, like in Spain (Camacho et al., 2020; Servillo \& De Bruijn, 2018), however, regarding the latter issue, rural areas in Poland have yet to make use of their significant potential (Szewranski et al., 2019). This would require deliberate support due to the "energy poverty" observed within Polish local communities (Piwowar, 2020).

Certain technical problems arose during the analysis process. The algorithm would at times fail to properly recognise a given sentence in pdf (Adobe Portable Document Format) documents (this was especially acute in the case of tables, page breaks, illustrations etc.). The phrases subject to automated search sometimes included from a few to several dozen words, which occasionally made it difficult to assess their meaning. $54 \%$ of records unrelated to Europe 2020 goals and to activity planned by a given LAG have been removed at the stage of analysing entire phrases. The qualification of the phrases was subjective, as it is difficult to apply strict logical and mathematical criteria in the qualitative assessment of the meaning of a sentence. The authors have thus concluded that the keyword search method should only be used for the preselection of data, though it may prove necessary when analysing a large number of documents (e.g. several hundred or more), as a single person would not able to read and methodically evaluate their content within reasonable time. This indicates a need to develop a two-step approach combining the objective approach of the algorithm with the subjective approach of the researcher. 
The results of the analysis, with research based on text mining methods, are largely consistent with the findings of analyses by authors making use of standard methodologies, i.e. they indicate that some of the goals of the Europe 2020 strategy which are related to modern technologies (target 2 and 3) may prove difficult to achieve through bottom-up, community-based development methods if they do not receive additional, targeted support.

Acknowledgments: This research was co-financed under the Leading Research Groups support project B190/0018/20 "Sustainable cities and regions" from the subsidy increased for the period 2020-2025 in the amount of $2 \%$ of the subsidy referred to Art. 387 (3) of the Law of 20 July 2018 on Higher Education and Science, obtained in 2019 by the Wroclaw University of Environmental and Life Sciences and within the framework of project No. 2019/33/B/HS4/00176 financed by the National Science Centre in Poland. English correction by R. Chytrowski.

\section{References}

Apostolopoulos, N., Liargovas, P., Stavroyiannis, S., Makris, I., Apostolopoulos, S., Petropoulos, D., \& Anastasopoulou, E. (2020). Sustaining Rural Areas, Rural Tourism Enterprises and EU Development Policies: A Multi-Layer Conceptualisation of the Obstacles in Greece. Sustainability, 12(18), 7687. https://doi.org/10.3390/su12187687

Bartniczak, B. (2012). State Aid as a Tool for Implementation of the Strategy "Europe 2020". In P. Jedlička (Ed.), Hradec Economic Days (Vol. 2, pp. 15-19). University of Hradec Králové.

https://uni.uhk.cz/hed/site/assets/files/1051/proceedings_2012_2.pdf

Biczkowski, M. (2020). LEADER as a mechanism of neo-endogenous development of rural areas: the case of Poland. Miscellanea Geographica - Regional Studies on Development, 24(4), 232-244. https://doi.org/10.2478/mgrsd-2020-0041

Böcher, M. (2008). Regional Governance and Rural Development in Germany: the Implementation of LEADER+. Sociologia Ruralis, 48(4), 372-388. https://doi.org/10.1111/j.1467-9523.2008.00468.x

Bosworth, G., Price, L., Hakulien, V., \& Marango, S. (2020). Rural Social Innovation and Neo-endogenous Rural Development. In E. Cejudo, \& F. Navarro (Eds.), Neoendogenous Development in European Rural Areas: Results and Lessons (pp. 21-32). Springer Geography. https://doi.org/10.1007/978-3-030-33463-5_2

Boukalova, K., Kolarova, A., \& Lostak, M. (2016). Tracing shift in Czech rural development paradigm (Reflections of Local Action Groups in the media). Agricultural Economics - Czech (Zemědělská ekonomika), 62(4), 149-159. https://doi.org/10.17221/102/2015-AGRICECON

Camacho, J. A., Rodríguez, M., \& Sánchez, L. M. (2020). Employment and Job Creation in the LEADER Approach. In E. Cejudo \& F. Navarro (Eds.), Neoendogenous Development in European Rural Areas. Results and Lessons (pp. 235-250). Springer Nature Switzerland AG. https://doi.org/10.1007/978-3-030-33463-5_11

Canete, A. J., Navarro, F., \& Cejudo, E. (2018). Territorially unequal rural development: the cases of the LEADER Initiative and the PRODER Programme in Andalusia (Spain). European Planning Studies, 26(4), 726-744. https://doi.org/10.1080/09654313.2018.1424118

Castellano-Álvarez, F. J., Masot, A. N., \& Castro-Serrano, J. (2020). Intangibles of Rural Development. The Case Study of La Vera (Extremadura, Spain). Land, 9(6), 203. https://doi.org/10.3390/land9060203

Cejudo, E., \& Navarro, F. (2020). Neoendogenous Development in European Rural Areas. Results and Lessons. Springer Nature Switzerland AG. https://doi.org/10.1007/978-3-030-33463-5

Chruscinski, J., Kazak, J. K., Tokarczyk-Dorociak, K., Szewranski, S., \& Swiader, M. (2019). How to Support Better Decision Making for Sustainable Development? IOP Conference Series: Materials Science and Engineering, 471, 112008. https://doi.org/10.1088/1757-899X/471/11/112008

Dąbrowski, M. (2012). Shallow or deep Europeanisation? The uneven impact of EU cohesion policy on the regional and local authorities in Poland. Environment and Planning C: Government and Policy, 30, 730-745. https://doi.org/10.1068/c1164r

Esparcia, J., \& Abbasi, F. (2020). Territorial Governance and Rural Development: Challenge or Reality? In E. Cejudo, \& F. Navarro (Eds.), Neoendogenous Development in European Rural Areas (pp. 33-60). Springer Geography. https://doi.org/10.1007/978-3-030-33463-5_3

European Commission. (2010). Europe 2020. A strategy for smart, sustainable and inclusive growth, Communication from the Commission 3.3.2010 COM(2010). European Commission. https://doi.org/http://eur-lex.europa.eu/LexUriServ/LexUriServ.do?uri=COM:2010:2020:FIN:EN:PDF 
European Court of Auditors. (2010). Implementation of the LEADER approach for rural development. https://www.eca.europa.eu/Lists/ECADocuments/SR10_05/SR10_05_EN.PDF

Furmankiewicz, M., \& Campbell, A. (2019). From Single-Use Community Facilities Support to Integrated Sustainable Development: The Aims of Inter-Municipal Cooperation in Poland, 1990-2018. Sustainability, 11(21), 5890. https://doi.org/10.3390/su11215890

Furmankiewicz, M., Hewitt, R. J., Janc, K., \& Kazak, J. K. (2020). Europeanisation of energy policy and area-based partnerships: Regional diversity of interest in renewable energy sources in local development strategies in Poland. IOP Conference Series: Earth and Environmental Science 609, 012033. https://doi.org/10.1088/1755-1315/609/1/012033

Furmankiewicz, M., \& Janc, K. (2012). Partnerstwa terytorialne jako nowy model zarządzania rozwojem lokalnym - różnice regionalne i wpływ na aktywność mieszkańców. Studia KPZK, 140, 231-245. http://journals.pan.pl/dlibra/publication/111325/edition/96603/content

Furmankiewicz, M., Janc, K., \& Macken-Walsh, Á. (2016). The impact of EU governance and rural development policy on the development of the third sector in rural Poland: A nation-wide analysis. Journal of Rural Studies, 43, 225-234. https://doi.org/10.1016/j.jrurstud.2015.12.011

Furmankiewicz, M., Knieć, W., \& Atterton, J. (2015). Rural governance in the new EU member states: The experience of the Polish LEADER+ Pilot Programme (2004-2008). In J. Buček, \& A. Ryder (Eds.), Governance in Transition (pp. 133-153). Springer Geography. https://doi.org/DOI 10.1007/978-94-007-5503-1_7

Furmankiewicz, M., Królikowska, K., \& Przybyła, K. (2020). Goals of Elites and Local Communities in the European Union Neo-endogenous Development: Differences as the Constraints on Europeanisation? In P. Jedlička, P. Marešová, K. Firlej, \& I. Soukal (Eds.), Hradec Economic Days (Vol. 10, pp. 176-187). University of Hradec Králové. https://doi.org/10.36689/uhk/hed/2020-01-020

Gaikwad, S. V., Chaugule, A., \& Patil, P. (2014). Text Mining Methods and Techniques. International Journal of Computer Applications, 85(17), 42-45. https://doi.org/10.5120/14937-3507

Galindo-Pérez-de-Azpillaga, L., \& Foronda-Robles, C. (2018). Digital governance and information technologies in local action groups (LAGs). Cogent Social Sciences, 4, 1528730. https://doi.org/10.1080/23311886.2018.1528730

Hełdak, M., Stacherzak, A., \& Przybyła, K. (2018). Demand and Financial Constraints in Eliminating Architectural and Technical Barriers for People with Disabilities in Poland. Journal of Healthcare Engineering, 2018(1297396). https://doi.org/https://doi.org/10.1155/2018/1297396

High, C., \& Nemes, G. (2007). Social learning in LEADER: Exogenous, endogenous and hybrid evaluation in rural development. Sociologia Ruralis, 47(2), 103-119. https://doi.org/10.1111/j.1467-9523.2007.00430.x

Hoffmann, R., \& Hoffmann, N. (2018). The Leader Programme as an Impulse for New Projects in Rural Areas Quaestiones Geographicae, 37(2), 141-150. https://doi.org/10.2478/quageo-2018-0014

Hotho, A., Nürnberger, A., \& Paaß, G. (2005). A brief survey of text mining. LDV-Forum: Zeitschrift für Computerlinguistik und Sprachtechnologie GLDV-Journal for Computational Linguistics and Language, 20(1), 19-62. https://jlcl.org/content/2-allissues/24-Heft1-2005/19-62_HothoNuernbergerPaass.pdf

Hutchinson, J. (1994). The Practice of Partnership in Local Economic Development. Local Government Studies, 20(3), 335-344. https://doi.org/10.1080/03003939408433731

Janc, K., Raczyk, A., \& Dołzbłasz, S. (2020). Not Only in Cities: Creative Activities in Rural Areas with a Case Study of Lower Silesia. Quaestiones Geographicae, 39(2), 97-112. https://doi.org/10.2478/quageo-2020-0013

Kis, K., Gal, J., \& Veha, A. (2012). Effectiveness, efficiency and sustainability in local rural development partnerships. APSTRACT-Applied Studies in Agribusiness and Commerce, 6(3-4), 31-38. https://doi.org/10.22004/ag.econ.138118

Kola-Bezka, M. (2020). Are LAGs contributing to solving social exclusion problems? The case of Kujawsko-Pomorskie Voivodship. Bulletin of Geography. Socio-economic Series, 48, 35-45. https://doi.org/10.2478/bog-2020-0012

Konečný, O. (2019). The Leader Approach Across The European Union: One Method of Rural Development, Many Forms of Implementation. European Countryside, 11(1), 1-16. https://doi.org/10.2478/euco-2019-0001

Krajewski, P., \& Solecka, I. (2019). Management System of Urban Landscape in Poland on the Example of Wroclaw in the Context of European Landscape Convention Implementation. IOP Conference Series: Materials Science and Engineering, 471, 112035. https://doi.org/10.1088/1757-899X/471/11/112035

Ministerstwo Infrastruktury i Rozwoju. (2014). Zasady realizacji instrumentu "Rozwój lokalny kierowany przez społeczność w Polsce". Ministerstwo Infrastruktury i Rozwoju.

http://www.rpo.wzp.pl/sites/default/files/zasady_realizacji_rlks_02042014.pdf 
Ministerstwo Rolnictwa i Rozwoju Wsi. (2019). Program Rozwoju Obszarów Wiejskich na lata 2014-2020. Ministerstwo Rolnictwa i Rozwoju Wsi.

https://www.gov.pl/web/rolnictwo/-program-rozwoju-obszarow-wiejskich-2014-2020-prow-2014-2020

Moseley, M. J. (Ed.). (2003). Local Partnerships for Rural Development. The European Experience. CABI Publishing.

Navarro, F. A., Cejudo, E., \& Maroto, J. C. (2016). Participation of disadvantaged groups and governance in the LEADER and PRODER programmes in Andalucía, Spain. Studies in Agricultural Economics, 118, 47-54. https://doi.org/10.7896/j.1532

Navarro, F. A., Woods, M., \& Cejudo, E. (2016). The LEADER Initiative has been a Victim of Its Own Success. The Decline of the Bottom-Up Approach in Rural Development Programmes. The Cases of Wales and Andalusia. Sociologia Ruralis, 56(2), 270-288. https://doi.org/10.1111/soru.12079

Novikova, M., de Fátima Ferreiro, M., \& Stryjakiewicz, T. (2020). Local development initiatives as promoters of social innovation: Evidence from two European rural regions. Quaestiones Geographicae, 39(2), 43-53. https://doi.org/10.2478/quageo-2020-0012

Piwowar, A. (2020). Outline of the Problem of Energy Poverty in Poland - Trend and Extent. In P. Jedlička, P. Marešová, K. Firlej, \& I. Soukal (Eds.), Hradec Economic Days (Vol. 10, pp. 634-641). University of Hradec Králové. https://doi.org/20.500.12603/273

Ray, C. (2006). Neo-endogenous rural development in the EU. In P. Cloke, T. Marsden, \& P. Mooney (Eds.), Handbook of Rural Studies (pp. 278-291). Sage. https://doi.org/10.4135/9781848608016.n19

Rodriguez, M., Sanchez, L. M., Cejudo, E., \& Camacho, J. A. (2019). Variety in local development strategies and employment: LEADER programme in Andalusia. Agricultural Economics - Czech (Zemědělská ekonomika), 65(1), 43-50. https://doi.org/10.17221/106/2018-AGRICECON

Rounds, R. C. (Ed.). (1993). The structure, theory and practice of partnerships in rural development. Agriculure and Rural Restructuring Group, Rural Development Institute.

Servillo, L., \& De Bruijn, M. (2018). From LEADER to CLLD: The Adoption of the New Fund Opportunities and of Their Local Development Options. European Structural and Investment Funds Journal, 6(3), 223-233. https:/estif.lexxion.eu/data/article/13233/pdf/estif_2018_03-007.pdf

Stacherzak, A., \& Hełdak, M. (2019). Borough Development Dependent on Agricultural, Tourism, and Economy Levels. Sustainability, 11(2), 415. https://doi.org/10.3390/su11020415

Struś, M., Kalisiak-Mędelska, M., Nadolny, M., Kachniarz, M., \& Raftowicz, M. (2020). Community-Supported Agriculture as a Perspective Model for the Development of Small Agricultural Holding in the Region. Sustainability, 12(7), 2656. https://doi.org/10.3390/su12072656

Székely, V. (2017). Changes in commuting patterns in the territories covered by LEADER Local Action Groups: Slovakia, 2001 and 2011. Studies in Agricultural Economics, 119(1), 18-25. https://doi.org/10.7896/j.1072

Szewranski, S., Kachniarz, M., Sylla, M., Swiader, M., \& Tokarczyk-Dorociak, K. (2019). Spatio-temporal assessment of energy consumption and socio-economic drivers in rural areas in Poland. Engineering for Rural Development, 18, 1372-1378. https://doi.org/10.22616/ERDev2019.18.N093

Szewrański, S., \& Kazak, J. (2020). Socio-Environmental Vulnerability Assessment for Sustainable Management. Sustainability, 12(19), 7906. https://doi.org/10.3390/su12197906

Thuesen, A. A., \& Nielsen, N. C. (2014). A territorial perspective on EU`s LEADER approach in Denmark: The added value of community-led local development of rural and coastal areas in a multi-level governance settings. European Countryside, 6(4), 307-326. https://doi.org/10.2478/euco-2014-0017

Vrabková, I., \& Šaradín, P. (2017). The Technical Efficiency of Local Action Groups: a Czech Republic Case Study. Acta Universitatis Agriculturae et Silviculturae Mendelianae Brunensis, 65(3), 1065-1074.

https://doi.org/10.11118/actaun201765031065

Witherick, M., Ross, S., \& Small, J. (Eds.). (2001). A Modern Dictionary of Geography. Arnold.

Zajda, K. (2014). New Forms of Social Capital of Rural Areas. A Case Study of Selected Polish Local Action Groups. Lambert Academic Publishing. 